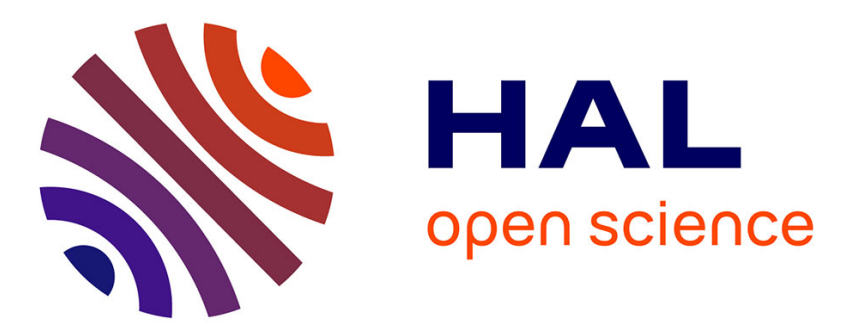

\title{
Drawing the Line. Visual Representations of the Labouring and Lower Classes in the Mid-Victorian Illustrated Press.
}

Françoise Baillet

\section{- To cite this version:}

Françoise Baillet. Drawing the Line. Visual Representations of the Labouring and Lower Classes in the Mid-Victorian Illustrated Press.. Etudes Anglaises, 2017, 70 (4), pp.406-428. hal-02171969

\author{
HAL Id: hal-02171969 \\ https://hal.science/hal-02171969
}

Submitted on 3 Jul 2019

HAL is a multi-disciplinary open access archive for the deposit and dissemination of scientific research documents, whether they are published or not. The documents may come from teaching and research institutions in France or abroad, or from public or private research centers.
L'archive ouverte pluridisciplinaire HAL, est destinée au dépôt et à la diffusion de documents scientifiques de niveau recherche, publiés ou non, émanant des établissements d'enseignement et de recherche français ou étrangers, des laboratoires publics ou privés.

\section{(ㄷ)(i) $\Theta$}

Distributed under a Creative Commons Attribution - NoDerivatives| 4.0 International 


\title{
Drawing the Line. Visual Representations of the Labouring and Lower Classes in the Mid-Victorian Illustrated Press.
}

\begin{abstract}
As part of their commitment to topicality, one of the fundamental premises of the Victorian illustrated press, The Graphic (1869-1932) and The Illustrated London News (1842-2003) devoted significant space to the representation of urban poverty. At a time when the discussions around the extension of the franchise provided a tribune for latent tensions between bourgeois power and working-class rise, citizenship came to be defined in terms of social and cultural identities, prompting an exclusive discourse which pervaded the whole political spectrum.

Concentrating on a selection of illustrations published between the mid-1860s to the late 1870s, this article purports to examine the way in which this exclusive discourse was articulated by the Illustrated London News and the Graphic, illuminating the conflict between the newspapers' stated aim of providing a truthful record of everyday events and the images produced. Its central assertion is that the artistic, satirical and technical filters used by the draughtsmen in these representations helped to establish a distinction between "deserving" and "undeserving" poverty. By drawing a literal line between suitable and unsuitable citizens, these periodicals articulated a reassuring visual discourse relying on a shared set of assumptions between artists, editors and readers about what the political nation should become.
\end{abstract}

Engagés dans une démarche de fidélité à l'actualité, l'une des principales ambitions de la presse illustrée victorienne. The Graphic (1869-1932) et The Illustrated London News (1842-2003) ont consacré une part significative de leurs publications à la représentation de la pauvreté urbaine. A l'heure où les débats autour de l'extension du suffrage font affleurer les tensions entre pouvoir bourgeois et montée de la classe ouvrière, c'est en termes d'identités sociales et culturelles que se définit la citoyenneté britannique, objet d'un discours clivé dans l'ensemble de la classe politique.

À travers une sélection d'illustrations publiées entre le milieu des années 1860 et la fin de la décennie suivante, le présent article s'attache à analyser la façon dont ces partis pris ont trouvé voix dans les pages de l'Illustrated London News et du Graphic, soulignant une forme de contradiction entre l'objectif affiché par ces journaux, celui d'un réalisme presque photographique, et les images produites. Elaborées au prisme de filtres artistiques et satiriques et reproduites en fonction de contraintes techniques lourdes, ces représentations ont contribué à établir une distinction entre pauvreté "respectable" et déchéance sociale. En traçant une ligne de partage littérale entre dignité et indignité, ces périodiques se sont fait le relais d'un discours visuel rassurant et largement partagé quant à l'avenir de la nation britannique.

If the pen be ever led into fallacious argument, the pencil must at least be oracular with the spirit of truth. (“Our Address", Illustrated London News, 14 May 1842, 1)

From its foundation in May 1842, the Illustrated London News, Herbert Ingram's pioneering venture into pictorial journalism, aimed to provide its readers with up-to-date information. In a fast-evolving news cycle in which the provision of factual information was paramount, it attempted to offer an open window onto the world, to place "under their glance, and within their grasp, the very form and presence of events as they transpire, in all their substantial reality, and with evidence visible as well as circumstantial" (Illustrated London News, 14 May 1842, 1). This commitment to topicality, one of the fundamental components of the Victorian illustrated press, largely relied on technological innovation, particularly on the use of wood-engraving, which, unlike early nineteenth-century copper or steel engravings, could be produced quickly and then printed alongside letterpress text (Young 26). In 1869, the founding of the Graphic, another lavishly illustrated weekly, confirmed the popularity of wood-engravings. Launched and published by William Luson Thomas, The Graphic offered a new departure, a distinctive approach to news illustration which Joseph Hatton, editor of the 
Sunday Times from 1874 to 1881, records in his volume on Journalistic London: "it was fresh, it was progressive; there was no other paper like it" (Hatton 232). A former assistant to the engraver William James Linton, supporter of radical causes and Chartist sympathiser, Thomas rejected the mechanically-produced image of its main rival, the Illustrated London News, encouraging instead "an artistic and subjective approach to news illustration" (Korda 9). According to the progressive policies of the Graphic, draughtsmen and engravers were not to be treated like factory workers, but like artists, and even owners (Korda 50). Both newspapers, however, shared a strong commitment to topicality, aiming to produce visual accuracy and "to place before the public a journal which shall be worthy of preservation as an artistic record of the times in which we live" (The Graphic 1, Dec. 1869-June 1870, Preface, v).

As part of this commitment, the Graphic and the Illustrated London News devoted significant space to the representation of poverty. Pictorial interest for the poorer classes of society had begun in the 1840s. Largely inspired by successive reports and news items about children's or women's working conditions, several painters and black-and-white artists had attempted to depict such scenes, drawing attention to their plight. ${ }^{1}$ The time span covered here, from the mid-1860s to the 1870 s, corresponds to a critical period in the depiction of the working classes, in which the social realists, some of whom worked as illustrators for the Graphic, were more forthright in confronting the suffering of the working classes in both town and country (Cowling 188). Until the 1860s and the 1870s, and with the notable exception of Kenny Meadows's "Characters about Town" (Meadows 298), the urban poor and labouring classes had not been a regular feature of the periodical press, the Illustrated London News in particular (Wolff \& Fox 568). One of the reasons for this increasing visibility may have been the political and social context of the day, when discussions around the extension of the franchise led to a redefinition of the notion of citizenship. The discussions around the Second Reform Act (1867) provided a tribune for latent tensions between bourgeois power and working-class rise. Fuelled by the writings of such commentators as Bagehot, some Victorians expressed apprehensions as to the possible perils of democracy (Hoppen 482-83).

These fears, however, did not concern all the poorer classes indiscriminately. Historians of the period have highlighted the ambiguity of the term "poor," showing that definitions of the underclass varied throughout the nineteenth century, and reflected "the distinctive economic, political, and social contexts of particular periods" (Welshman 5). In his writings on the Elizabethan Poor Laws, Jeremy Bentham had already established a strong distinction between poverty and indigence. Poverty, Bentham remarked,

is the state of everyone who, in order to obtain subsistence, is forced to have recourse to labour. Indigence is the state of him who, being destitute of property (or at least destitute of the species of property necessary to the immediate satisfaction of the particular want by which he happens to be pressed), is at the same time unable to labour, or unable, even for labour to procure the supply of which he happens thus to be in want. (Bentham 3)

\footnotetext{
${ }^{1}$ See John Leech, "Capital and Labour," Punch vol. 5 (July 29, 1843), Thomas Hood, "The Song of the Shirt," Punch vol. 5 (Dec. 15, 1843), or Richard Redgrave, "The Poor Seamstress," 1846.
} 
To this definition, and in the spirit of the 1834 Poor Law Amendment Act, the Victorians added a further distinction between incapacity and unwillingness to work. One of the key concepts informing Victorian political thought and social sciences at large was that all ablebodied poor were considered as "undeserving." Among them, the "residuum" was deemed the most dangerous for the social fabric. First specifically formulated by John Bright, radical MP for Birmingham, during the debate on the Second Reform Act in March 1867, the "residuum" defined this section of the population which, Bright contended, should not be enfranchised (Hansard, $3^{\text {rd }}$ ser., vol. 186, cols. 626-42 March 1867). In a context influenced by the Marxist concept of Lumpenproletariat and wider fears of criminal classes, citizenship came to be defined in terms of social and cultural identities, prompting an exclusionary type of discourse which pervaded the whole political spectrum. Discussions on pauperism concerned moral rather than structural issues, establishing a strong distinction between the "decent man" and the "rough," between "deserving" and "undeserving" poverty.

Concentrating on the mid-Victorian era, from the mid-1860s to the late 1870 s, this article purports to examine the way in which this discourse of exclusion was articulated in the Illustrated London News and the Graphic. Current scholarship on nineteenth-century print culture has largely documented the attitude of Victorian newspapers to urban problems, highlighting the fact that the "rise of the mass circulation illustrated newspaper did not necessarily bring with it serious graphic reportage of social conditions" (Fox 1977, 111). As represented by the "special artists" of the Graphic and the Illustrated London News, the reality of working-class life tended to disappear behind pictorial codes, offering what Celina Fox calls a "blinkered approach" (Fox 1977, 94). More recently, Peter Sinnema has focused on the representation of poverty in the Illustrated London News as an instance of ideological discourse rather than as an accurate depiction of reality, a viewpoint shared by Joshua Brown, whose volume on pictorial reporting emphasises its dramatic portrayal of nineteenth-century news (Sinnema 2, Brown 72). In her recent study on Printing and Painting the News in Victorian London, Andrea Korda explains this shift by a growing divide across the visual field between "the modern image, characterized by its literal description and objectivity" and "the modernist work of art, defined by its autonomy and, increasingly, by its rejection of realistic representation" (Korda 4). Building on these investigations, this article focuses specifically on the use of aesthetic and satirical representational codes as visual discourse on poverty in the Illustrated London News and the Graphic. Its central assertion is that the artistic filters used by draughtsmen in these representations helped to establish a distinction between "deserving" and "undeserving" poverty. By drawing the line between suitable and unsuitable citizens, these periodicals articulated a reassuring visual discourse relying on a shared set of assumptions between artists, editors and readers about what the political nation would become.

I first consider a number of depictions of work and workers through the filter of what Paul Dobraszczyk calls the "rhetorical sublime" (358). Building on Dobraszczyk's approach, I investigate the trope of the sublime as a way to address, explore, and (re)construct the notion of industrial masculinity, to promote industrial progress and to offer the Victorian public a 
way to shield themselves from harsh social realities. The next section of the article explores the process of aesthetic (re)construction of poverty. Focusing on depictions of paupers, but also of women and children at work, I examine a number of pictorial as well as technical filters used by the Graphic and the Illustrated London News in their attempt to present their readership with sanitised versions of urban scenes. This aestheticisation of poverty was supported by advances in wood-engraving technology, which enhanced these effects (Sinnema 30). The final part of the article considers the representational strategies used by these periodicals to "draw the line" between respectable and "dangerous" poverty. Here, images of "undeserving" paupers are examined as a way for the Graphic and the Illustrated London News to generate a sense of distance between the subjects and spectators of art. By stigmatising the degraded poor, authors and readers were able to draw a line between self and other, to construct a reassuring sense of difference.

\section{Workers and the Industrial Sublime}

In its second issue, the Illustrated London News defined its mission:

Whenever society is shocked and degraded by crimes so vast in magnitude and so deep in dye as those we have recently seen committed and condemned, we will seek to infuse a healthier tone of morality into the popular mind upon the subject of such dismal atrocities - to diminish the wild and dreadful excitement which at such moments agitate the public frame, and to cleanse that bad and brutal spirit which is fond of revelling in execration, and makes a holiday spectacle of the crisis which sends the murderer before his God. ("Our Principles," Illustrated London News 2:1, 21 May 1842)

Investing visual art with a moral mission, The Illustrated London News aimed "to inform the minds of men, and to elevate them through art's permanent qualities - the universality, truthfulness and entireness of its instruction" (ILN 2:1, 21 May 1842). The textual and the visual, it argued, could combine information with instruction and thus promote moral elevation. From its early days, the Illustrated London News had hired a number of renowned illustrators and engravers such as "Phiz" (Hablot Knight Browne), Randolph Caldecott, Walter Crane, George Cruikshank, Gustave Doré, William Harvey, W.J. Linton, and Charles Keene-also a prominent Punch contributor (Vann and Van Arsdel 137). These lofty ideals were shared by its main competitor, the Graphic, which, in its opening volume, acknowledged the "numerous distinguished Artists" whose contribution would enable the newspaper to infuse the mundane with a sense of beauty normally associated with "high" art (Preface v). The leading policy of the Graphic editors was "not to confine the illustrations, as had hitherto been the case in illustrated papers, to a special staff of draughtsmen on wood, but to welcome any artist of talent, no matter what medium he used" (Hatton 235). It therefore employed a long list of painters, some of whom were prominent members of the Royal 
Academy, such as Luke Fildes, Hubert von Herkomer, John Everett Millais, and Frank Holl, who worked under the supervision of the journal's art editor. Writing for the Magazine of Art in 1883, Harry V. Barnett argued that imagination, rather than realism, was essential for the special artist: "Sketches which are destitute of spirit and innocent of imagination, however full and accurate in detail are not properly realistic; they are dull and unsuggestive - they are the raw material, the commonplaces of illustrated journalism" (Barnett 166). The ideal special artist, he suggested, must be gifted above all with the "power of investing bare facts with charm, and vivifying them with spirit" (Barnett 164).

This dramatization of everyday life is strikingly apparent in a series depicting industrial scenes and published by the Graphic in the early months of 1871. "King Coal at Home" was accompanied with several wood engravings by Matthew White Ridley (1837-88), a former Royal Academy student who had produced noteworthy illustrations for Cassell's Family Magazine and the Quiver. His illustration "Pitmen Hewing the Coal," published on January 28, 1871, represents a "working board" of five miners as they hew and then load coals onto a horse-drawn mine wagon or tram (figure 1).

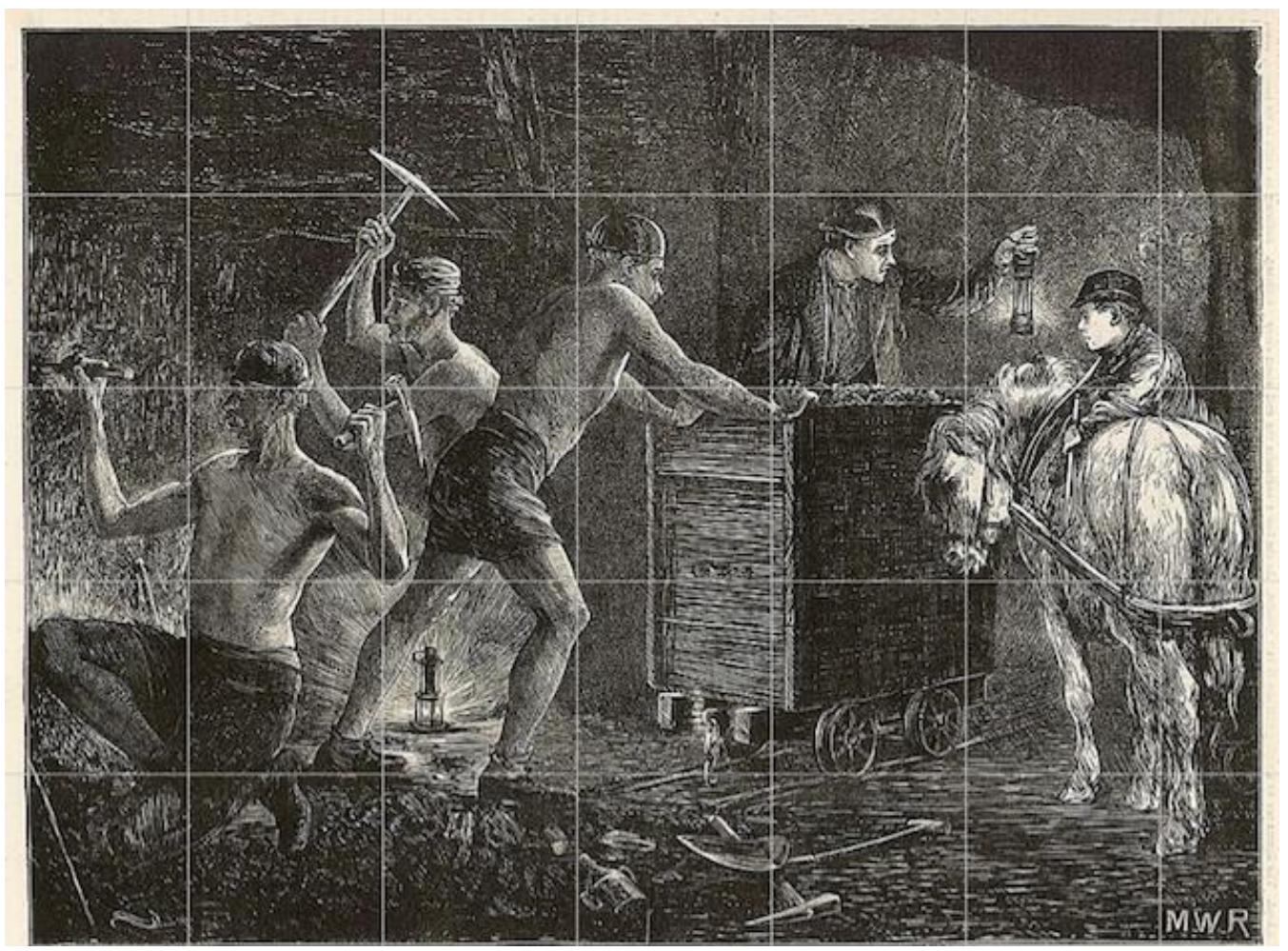

Fig. 1: Mathew White Ridley, "Pitmen Hewing the Coal," Graphic 3 (Jan. 28, 1871): 77

The picture is constructed around the central figure of the putter, whose stately shape, lit from below, stands out against the dark background. With his firmly delineated silhouette, muscular limbs, and vigorous demeanour, the young miner embodies industrial masculinity. On either side of his dignified figure stand pairs of workers, hewers on the left and pony 
putters on the right. ${ }^{2}$ Riley creates a striking chiaroscuro effect, placing two Davy-lamps on either side of the composition. The resulting contrast, this "sudden alternation of light and dark" - one of the techniques of the sublime as defined by Burke in 1757 (Klingender 84) outlines the workers' figures, emphasising their muscles and joints and achieving a sense of volume. This treatment of light and shadow is enhanced by the strength and clarity of woodengraving technique, which dramatises the scene with fine delineations of form. In the accompanying article, the Graphic acknowledges Ridley's "slight sacrifices to artistic effect." Rather than attempting to provide a realistic rendering of the various tasks performed by the Durham miners, Ridley's plate echoes and comments upon contemporary painting, a set of references all the more significant as they were likely to have been shared by the Graphic's middle-class readership. A few years before, in Work (1865), Ford Madox Brown had also painted a heroic worker dignifying an ordinary scene, to articulate an ideology of progress. The male worker's body thus becomes an instance of ideological discourse, articulating national superiority and technological progress. In a context dominated by cultural constructions glorifying work-Carlyle's "Laborare est Orare, Work is Worship" (200) - it testifies to the correlation between physical appearance and the ability to respond to the exigencies of production. Indeed Victorian masculinity, Herbert Sussman remarks, is "not conferred in moments of revelation, but acquired through hours of hard work, not absorbed through wise passiveness, but achieved through strenuous activity" (118). In this Victorian dialectic between work and manliness, the quest for respectability rested upon the assumption that "the evident inequalities within English society could be surmounted by individual effort and achievement" (Lorimer 111).

This idealisation of the male body was emphasised by the printing technologies employed by the Graphic and the Illustrated London News. Wood-engraving, revived in the late 1850s with the Moxon edition of Tennyson's poems, produced finely delineated, highcontrast images that stressed the nobility of the subjects represented (Goldman 2). As Jim Mussell points out, wood-engraving connoted a "degree of gentility" (74). ${ }^{3}$ While woodcuts were associated with the crude and sensational popular press, wood-engravings had "aesthetic links to fine art prints and books [and] seemed thoroughly respectable" (Beegan 55). Cut on the end grain rather than on the flank of the block, they allowed the engraver to create lines that came close to the fineness that could be achieved by engraving on metal (Goldman and Cooke 36). Filtering industrial scenes through such an artistic idiom was a way for illustrated periodicals to fulfil the expectations of their metropolitan, middle-class readers, who presumably were unwilling to confront the human consequences of the ideology of progress they believed in.

"Coal Whipping in the Pool," another instalment in Ridley's "Pits and Pitmen" series, published on February 25, 1871, establishes the same kind of artistic connivance with readers of the Graphic. However, instead of focusing on workers' bodies, it emphasises industrial

\footnotetext{
${ }^{2}$ Pony putters: the drivers of a pony drawing a mine waggon.

${ }^{3}$ Gerry Beegan further remarks that the "Illustrated London News asserted its middle-class character not only through the content of the images it printed but also through the reproductive method it used." (Beegan 55).
} 
sublimity. The coal is "whipped," that is, discharged from the ship into baskets by a system of ropes and pulleys and then loaded onto a barge Ridley's frontal perspective on the scene allows him to offer the viewer a compelling vision of the cargo itself, along with two groups of "whippers": those standing on the derrick in the upper part of the plate and the others pulling on a rope in the lower part (figure 2).

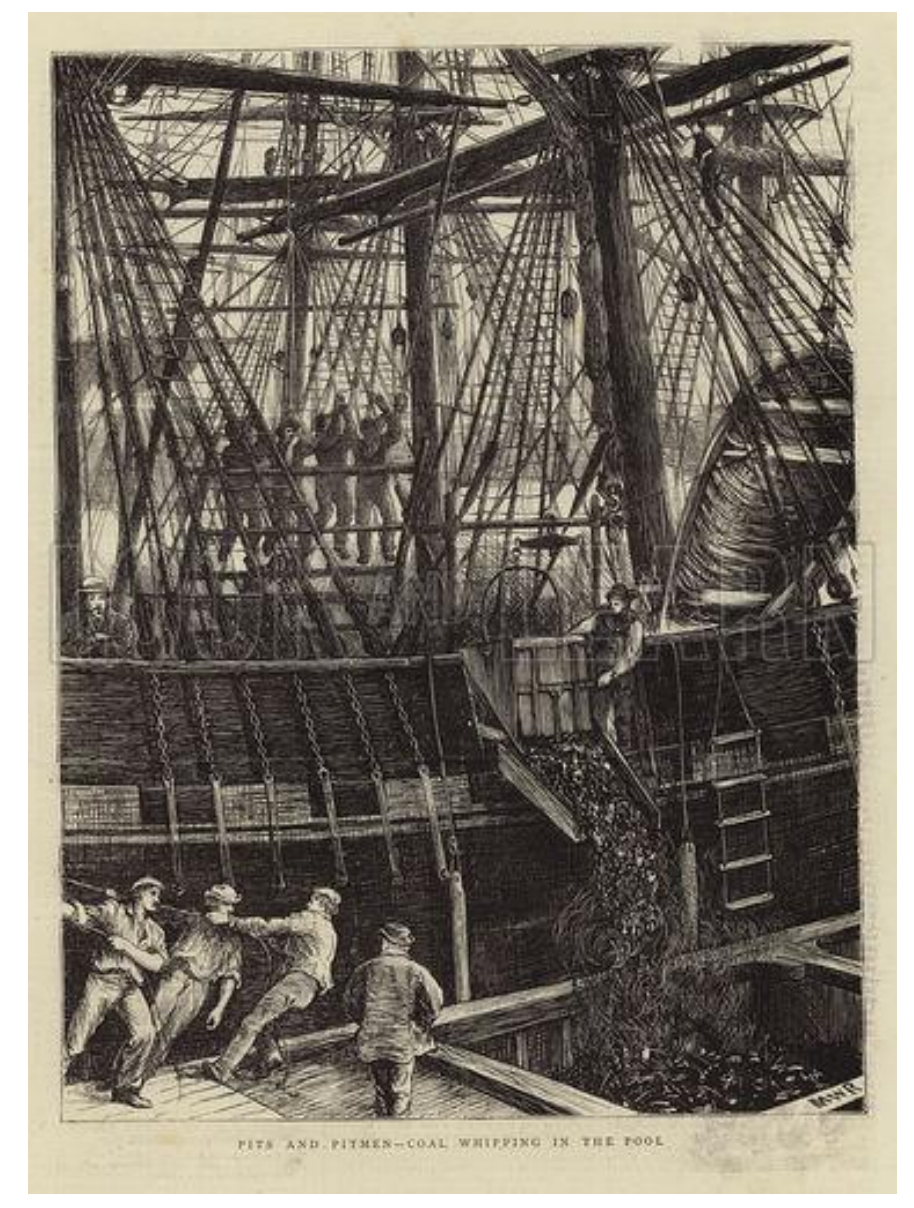

Fig. 2: Mathew White Ridley, "Coal Whipping in the Pool," Graphic 3 (Feb. 25, 1871) : 173

Defying its own commitment to accuracy, as implied by the technical details in the accompanying article, the image offers a celebration of industrial power. The vessel, with its massive black hull and powerful rigging, seems to exemplify the achievements of modernity. The artist's meticulous treatment of the ship's majestic proportions draws attention to the men's diminutive presence. Ridley's subtle use of light and shadow, which is reversed in the upper and lower parts of the picture, adds even more impact. In doing so, it unmistakably evokes other pictorial hymns to industry, such as William Bell Scott's Iron and Coal on Tyneside in the Nineteenth Century (1856-61). Ridley's image depicts the "sense of exaggerated scale" which attempts to provoke an "awe-struck response" from the viewer (Dobraszczyk 358).

A similar strategy is apparent in a picture published in the Illustrated London News in November 1878 and entitled "Charging the Retorts at the Gas-Works" (figure 3). Its author, 
William Bazett Murray, was an illustrator who specialised in industrial drawings and whose work, Simon Houfe remarks (237), was admired by Vincent van Gogh during his English years. Murray's sketch accompanies an article presenting the Beckton Gasworks, a major London plant opened a few years before (1870) on the north bank of the Thames by the Gas Light and Coke Company. In line with the Illustrated London News's commitment to accuracy, the article provides readers with a carefully documented panorama of gas production in general, and of the retort-houses in particular. From the distillation of the coal "by the heat of underground furnaces" to the cooling of the gas produced through the long chimneys, each step of the manufacturing process is presented. This scientific and rational approach to the subject is complemented by a fascination for the gigantic aspect of the site and the machines. Beckton is thus described as "a remarkable creation of industrial entreprise, capital, and labour" whose aspect is "very striking to passengers down the river." Its "[v]ast piles of building," "stately monumental clock-tower," and "immense gasholders" are notable, the author insists, for their "stupendous size" ("The Beckton Gasworks," ILN 73, 2 November $1878,411)$.

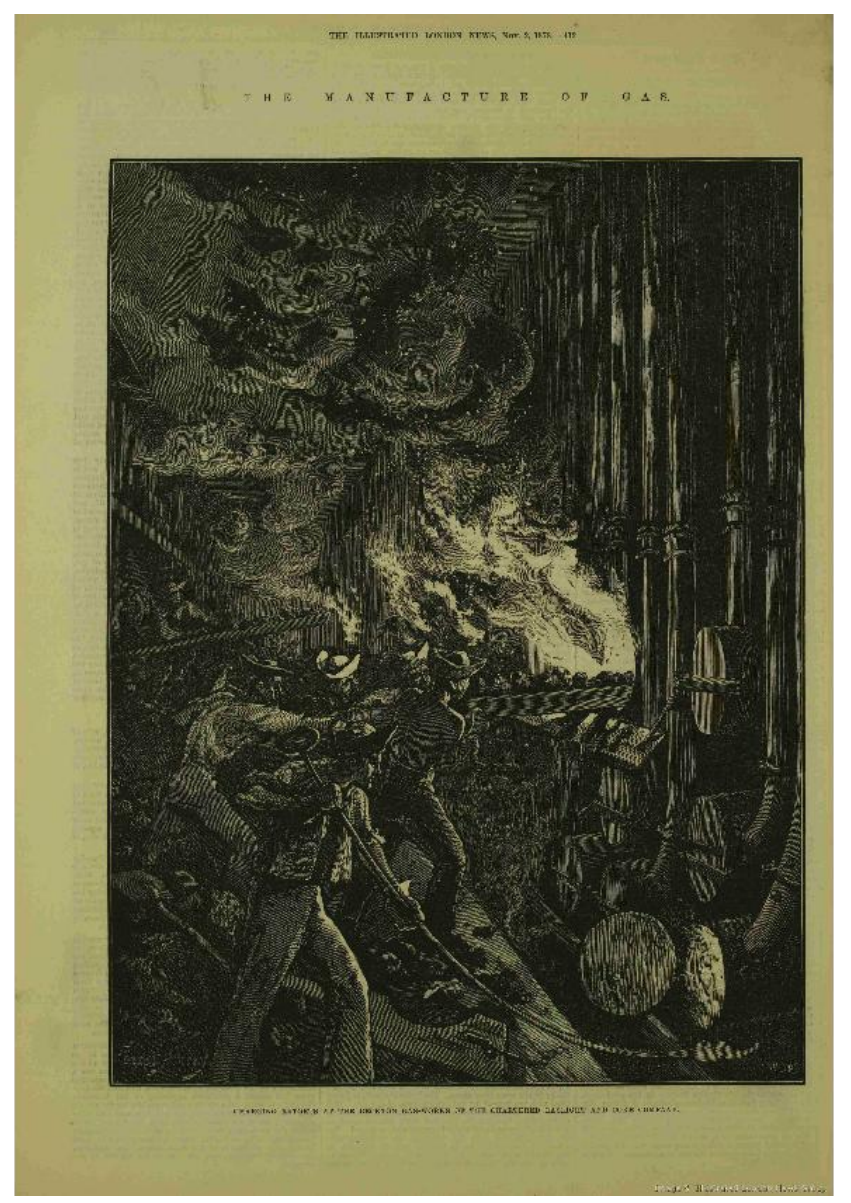

Fig 3 : William Bazett Murray, "Charging Retorts at the Beckton Gas-works of the Chartered Gaslight and Coke Company," Illustrated London News 73 (November 2, 1878) : 412 
Presented on a single page, Murray's picture quite strikingly conveys this fascination for industry. Here again, Burke's definition of the sublime - this "glaring brightness," "sudden alternation of light and dark" and "bitter tastes" and "intolerable stenches," Klingender 84applies everywhere, offering a striking representation of the stokers' work. The picture is constructed along the vertical lines formed by the retorts, whose pipes rise perpendicularly to the heaps of coals visible in the foreground, and to the workers charging them. The billowing white and dark flames bursting out of the open doors suggest a vision reminiscent of Gustave Doré's illustrations to Dante's Divine Comedy, completed only a dozen years before (186168). Their circular shape violently contrasts with both the ascending pipes on the right and the diagonals of the railway bridge, on which a train is seen coming, on the left. Between these antagonistic lines, the figures of the workers emerge powerfully in the foreground. With their dark and muscular forearms, their square shoulders and their energetic posture - particularly the stoker on the left, with his almost abnormally large shoulders-Murray's workers contribute to a visual discourse on manly power and productivity. This rendering of industrial work exemplifies what Dobraszczyk has described as the "rhetorical character" of some industrial scenes, where "images of industry [are] designed to have a deliberately persuasive or impressive effect" on the viewer (352). Subtly lit by the billows of steam coming from the furnaces, Murray's stokers are somehow dignified as they concentrate on their task, evoking such solemn representations as Joseph Wright of Derby's The Iron Forge (1776) or James Sharples's The Forge (1859). Forcefully engraved by William James Palmer, a prominent wood-engraver who had been apprenticed to the Jackson brothers and who also worked for Barnard and Overend (Engen 199-200), Murray's dramatic and rigorous sketch seems to reference what Herbert Sussman defines as the "regulated, disciplined expression of powerful male energy," while at the same time depicting the London gas manufacturing trade (Sussman 116). In spite of its oppressive atmosphere, Murray's picture appears as a work of art which dignifies the stokers, obliterating the effects of hard work on their bodies and dispelling the uneasiness which might arise from viewing such scenes.

Intended to evoke a strong emotional response from the viewers, and elevated by wood-engraving technology, the trope of the industrial sublime as used in the Graphic and the Illustrated London News thus prompted the readers to imagine the world rather than look at it, to evade rather than confront the truth of industrialism. However, images of the lower classes were also (re)constructed through the use of other filters, ranging from the picturesque - or deviations from it - to high art. Adapted and transformed by artist and engraver, the figures in the scenes were sometimes reinvented to suit both the medium of wood-engraving and the expectations of readers and publishers.

\section{Women, Children, and the Aestheticization of Work}

In May 1871, the Graphic (467) published "The Matchmakers at the East-End" together with an article purporting to offer a "brief account of a visit to Messrs. Bryant and May's match manufactory in the Fairfield Road, Bow" (figure 4). This firm employed a large number of women workers in the East End, many of whom suffered from "phossy jaw," a 
potentially fatal necrosis contracted during the manufacture of white phosphorus-tipped "Lucifer matches." The disease had been in existence since the 1830s and had been the subject of an article by Charles Dickens published in Household Words in 1852, as well as a series of reports by the Medical Society of London published in the 1860s (Raw 93). The "safety match," a safe alternative using red phosphorus, already existed but was only produced by Bryant and May in limited quantities due to the popularity of Lucifer matches.

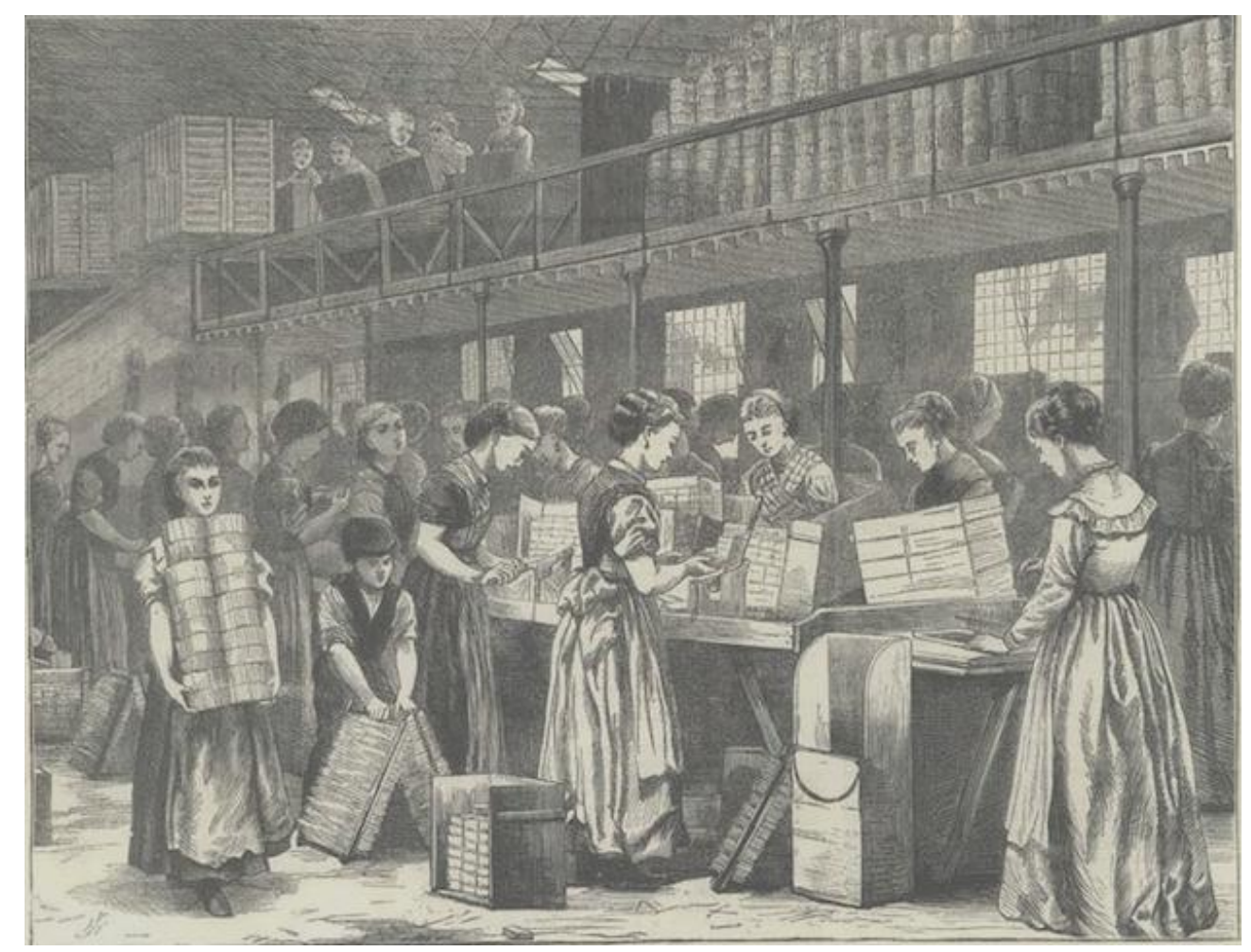

Fig. 4: Herbert Johnson, "The Matchmakers at the East-End," Graphic 3 (May 20, 1871) : 469

The artist for the Graphic was Herbert Johnson, a draughtsman and painter who specialised in military and ceremonial subjects. ${ }^{4}$ In the illustration, he depicts the production of "safety matches," thereby giving credit to Bryant and May's claim that the disease was "unknown in their establishment" and was instead produced by a "scourge of the small matchmakers, who work in ill-ventilated rooms." "Far from the sick and emaciated women described by Dickens (152) or John Bristowe a few years before, Johnson's matchmakers are rendered in picturesque terms. Standing around a large rectangular work surface, a dozen young "boxers" sort and pack matchboxes to be dispatched across the country and abroad. With their graceful and idealised figures, they are also more reminiscent of contemporary portraits of bourgeois women than of the malnourished factory girls Bryant and May were accused of ruthlessly exploiting. On the right-hand side of the picture, the worker's well-cut, glossy frock evokes

\footnotetext{
${ }^{4}$ A future "special reporter" on the Royal Tour of India of 1875, Johnson had then already exhibited work at the Royal Academy, including portraits of the Prince of Wales and royal family (Wood 283). ${ }^{5}$ According to Louise Raw, this was a false claim on their part. During this period, Bryant and May were actively involved in producing Lucifer matches (Raw 93).
} 
Millais's Black Brunswicker (1860), in which a woman tries to prevent her fiancé from leaving for battle. This illustration does not highlight the grim reality of such work, which, as Murdoch has shown, resulted in the "growth deformities caused by sitting in the same position, repeating the same motions hour after hour, day after day" (Murdoch 176). Rather, the illustration depicts five young and healthy women. As Fox points out, such images demonstrate the Graphic's "quest for higher things, a tasteful neutrality above the grubby strife-torn world, [which] suited admirably the growing market for respectable family reading matter" (Fox 1977, 93). Here again, beautifying the subject generates a pleasurable aesthetic sensation behind which the reality of working-class female work is safely diluted. Given the terrible effects of the match industry on women and children (see Raw 84-85), the Graphic felt the need to protect its family readership all the more acutely.

When "The Brickyards of England" series was published a few weeks later in the Graphic, the focus shifted from factory girls to children, offering yet another sublimated and non-threatening portrayal of underprivileged Victorians at work. Here again, the dilution of human suffering into classical references attempts to make a difficult subject matter palatable to a bourgeois audience. This time, Johnson depicts a small group of children as they come and go, carrying clay (figure 5).

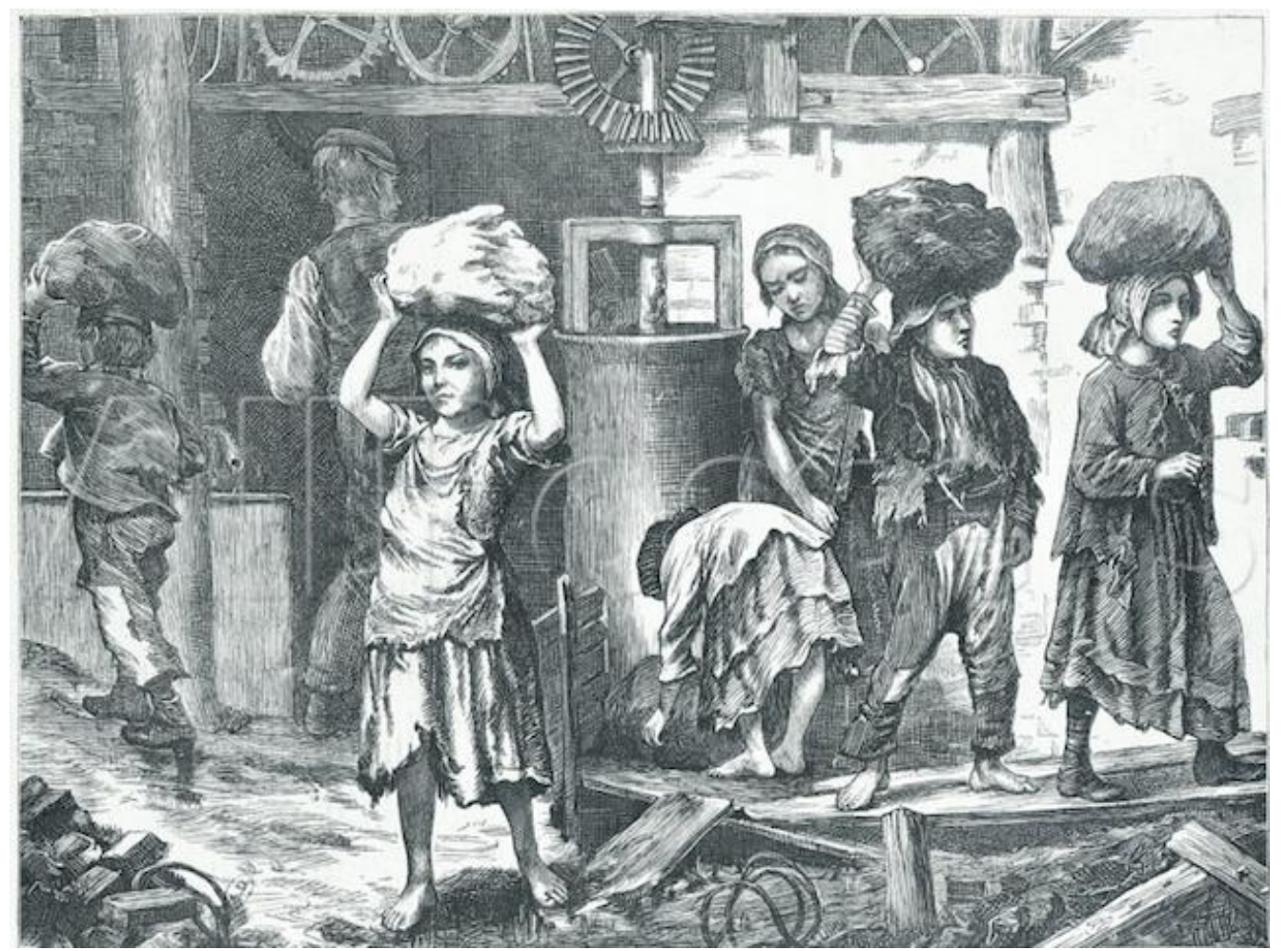

Fig. 5: Herbert Johnson, "The Brickyards of England - Children Carrying the Clay," Graphic 3 (May 27, 1871) : 493

In the Midlands, the cradle of the firebrick industry, children were often employed from the age of ten or younger and worked more than ten hours a day carrying as much as sixteen tons per day. Johnson's workers, with their well-fed bodies and classically shaped faces, create a sanitised vision of the industrial era that belies the actual strenuousness of factory work and 
its physical effects on overexploited children. The girl in the foreground carrying bricks on her head is quite striking in this respect. With naked feet and ragged robes on her healthy, strong, and well-proportioned body, she evokes classical water-carrier figures which would have been familiar to an educated middle-class readership. As such, she illustrates Francis Klingender's definition of "sublime and picturesque," a shift of emphasis "from discovery to contemplation, and to the poetic recording of the artist's emotions in the face of the scene" (83). First invented by William Gilpin in the eighteenth century and concerned with the "rough and rugged," as opposed to Burke's "neat and smooth" conception of the sublime (Klingender 85), the picturesque had by the mid-Victorian period become a much less visible trope only used by pictorial reporters in their renderings of dire poverty. Hence, maybe, William Bell Scott's cynical quotation on the subject, according to which "[w]hatever we would consider undesirable as a personal adjunct or condition, this is what the picturesque painter for the most part covets for his canvas. Wild and gaunt features as well as artless and contented expression, dishevelled tresses or elf-locks, tattered garments, he prefers; beggary is the most picturesque condition of social life" (Scott 328). Although "The Brickyards of England" may not be accurately described as "picturesque," the picture appears as a derivation from this style, suggesting a stronger link to artistic tropes and conventions than to the reality of nineteenth-century children's work.

By choosing not to confront readers with harsh representations of child poverty (such as those produced from 1867 by Dr. Barnardo's charity mission in the East End), Johnson supported the Graphic's broader tendency to idealise the poor. However, the sense of aesthetic distance in his illustrations was also determined by technical considerations. Because drawings were conceived not as finished artworks but as material that would be interpreted by the engraver, illustrators assumed a limited role. Not only did the master engraver use his connections to find the right illustrator for any news item, but he also controlled the elaboration of the images themselves. Once selected, a drawing was reworked according to an editorial procedure Joshua Brown describes as "murky" (Brown 35). "The onthe-spot artist's scanty representation was shaped by the limitations of time and the chaos of circumstance," Brown contends, "but there could be little motivation for comprehensive sketching in the field when every artist knew that his work served as only the first step in an extended process of pictorial reproduction that would progressively reconfigure his interpretation" (84). Indeed, wood-engraving had specific exigencies in terms of composition and scale. As a result, Beegan explains, "illustrators needed to learn to make drawings that could be easily and successfully engraved [...] In many cases the draftsman adjusted the originals provided by these artists to prepare them for cutting" (Beegan 52).

Moreover, because artists were required to submit drawings on a regular basis with very little advance notice, they relied on stock figures, compositions, and themes instead of engaging in the time-consuming process of observing the subjects represented. As Mussell points out, many published images were actually "drawn in-house and were based upon either textual accounts or other visual representations of the event, possibly from other publications, or were cobbled together on the basis of stock images and the inspiration of the artist" (Mussell 79). Hence, drawings lost accuracy and precision because the artist had to 
reconstruct the scene from interpretation or memory. Often, black-and-white artists would remain far from the scene of the news item and rely on general "fillers," more specifically topical illustrations drawn in advance of a predictable annual social event or a change of season" (Wolf \& Fox 563. See also Brown 100, Beegan 54).

Viewed through an aestheticizing lens and distorted to some degree by the specific exigencies of wood-engraving, the Graphic's renderings of factory women and children produce an idealised (re)construction of working-class life. Such representations depended upon artists', editors' and readers' assumptions about how factory work should be imagined, thus reinforcing the distance between the scenes observed and the images produced. This ideal is also apparent in Edwin Buckman's "Homeless," published in the Illustrated London News a few days before Christmas 1877 (figure 6).

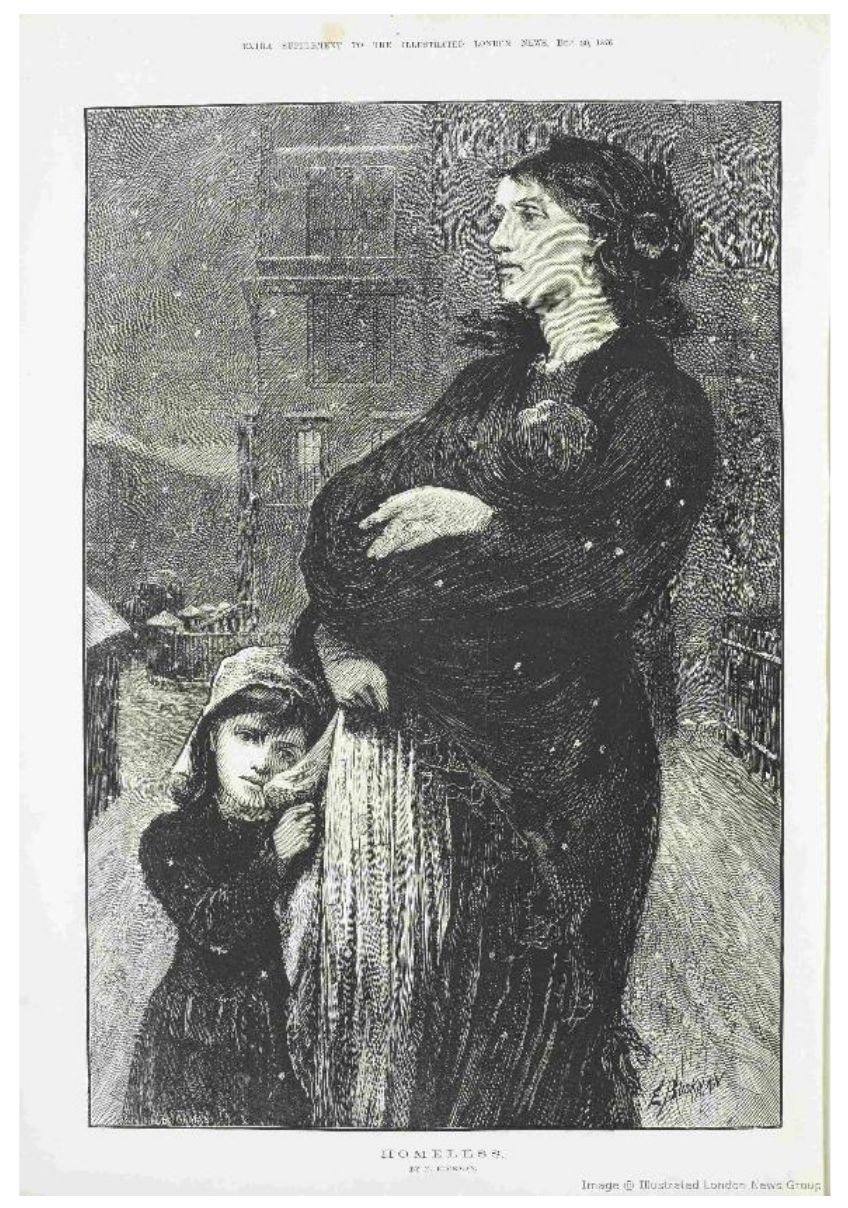

Fig. 6: Edwin Buckman, “Homeless,” Ilustrated London News 69 (Dec. 30, 1876) : 633

Buckman was an influential contributor to the Graphic from 1869 to 1871 and then to the Illustrated London News from 1871 to 1876, in addition to exhibiting at the Royal Watercolour Society and the Royal Academy until 1877 (Engen 36). In "Homeless," he depicts a young mother standing with her two small children in a snowy, deserted street. Her regular profile, vigorous body, perfect proportions, flawless skin, and elaborate hairstyle contradict the grim reality of vagrancy as it was then experienced by thousands of people, women in particular. The baby she is holding against her bosom adds to the symbolic 
dimension of the picture, assimilating her into the canon of the mater dolorosa. Close to her, her little daughter tilts a round-shaped, regular, and harmonious face sideways while her neatly combed and curly hair brushes against her mother's dress. Steeped in pictorial conventions, Pre-Raphaelite social paintings in particular, Buckman's picture is reminiscent of Dante Gabriel Rossetti's definition of a portrait which should be not "the icy double of the facts, but the reflection of a living image in the mind. An art of mere imitation or realism misrepresented the world, depicting it as without design or finish, unbalanced, unfitting" (Bartram 132). An abstract commentary on homelessness rather than the reflection of an actual street scene, "Homeless" reveals "the divinity that is within us" (Bartram 128). Himmelfarb notes that from mid-century the extreme poverty of London slums became the subject of "reports and parliamentary debates, statistical analyses and sensationalist exposés, sermons, articles, novels, even poems" (707). Series such as Mayhew's essays for the Morning Chronicle or Dickens's articles for Household Words exposed the dire sanitary conditions in which many East Enders were forced to live, generating among Victorian readers an anxiety also fuelled by reports on starvation, destitution, homelessness, and crime. Poverty was commonly associated with vice, and consequently female paupers were often portrayed as sexually promiscuous and destitute children as juvenile delinquents. Buckman's depiction of the scene stands in sharp contrast to these precursors by emphasising the dignity of the beggarly mother, whose proud and distant gaze connotes determination in adversity. The little girl's humble and subdued expression shields readers from confrontation, constructing them instead as charitable observers of the scene. By using the trope of the dependent poor - a woman and a child in need of protection - the artist constructs viewers as paternal figures, thus reinforcing their superior relationship to the subject represented. "The image of the martyr," Sheila Smith remarks, "diminishes and reduces the poor as much as does the image of the savage or the slave" (24). This expresses an ideology of social control and superiority that would have been particularly gratifying to bourgeois readers of the Illustrated London News.

\section{The "Residuum" and the Legacy of Caricature}

While the artistic filters of high art allowed readers to fix the reality of the "other nation" along benign and non-threatening lines, aesthetic codes borrowed from the tradition of Regency caricature denoted a different perception of the subjects represented. As historians of the Victorian period have documented, contemporaries tended to perceive vagrants, and the poor in general, as comprising two clearly distinguishable moral categories: the "deserving individual, who exhibited qualities of thrift, sobriety, industry, piety", and the "undeserving" vagrant, the habitual or "casual" tramp (Vorspan 65). Writing for the Pall Mall Gazette in January 1866 about the Lambeth workhouse, James Greenwood established a recurrent distinction between the "decent men," industrious but unfortunate, and the "ruffians" and "dirty scoundrels," depraved and profligate (Freeman and Nelson 68-69). And although the Poor Law Amendment Act of 1834 did not officially distinguish between different grades of the able-bodied poor, the social debate was permeated with this distinction (Harris 73). A 
prevailing assumption at the time was the belief that immoral habits and behavioural patterns are communicable (Vorspan 68). With their aversion to regular employment, the "undeserving" poor could therefore contaminate the industrious working class, and eventually threaten the whole social fabric. Hence the need, maybe, to draw a clear-literal-line between respectable and dangerous poverty. Depicting the so-called "residuum" along caricatural lines could therefore be seen as one of the ways in which contemporaries dealt with these fears, "a form of commodification of class anxiety" (Maidment 20). Building on Mary Cowling's remarks about the use of phrenology and physiognomy in Victorian art as a way to "bring order into an ever-increasing, even bewildering variety of human types and social classes," Brian Maidment observes that the dominant modes through which Regency and early Victorian graphic accounts of the poor were constructed evoked "well established traditions of repulsion and contempt" (Cowling 1989: xix, Maidment 20).

This idea of a repulsive pauper is conveyed in a contemporary sketch created by Matt Somerville Morgan for the Illustrated London News, "Distress at the East-End" (figure 7). Set in a soup-kitchen in Ratcliff-Highway, one of the most run-down and dilapidated areas of the East End, the scene depicts two distinct groups of people divided by a pillar in the background, with the back view of a dark and sturdy volunteer in the foreground.

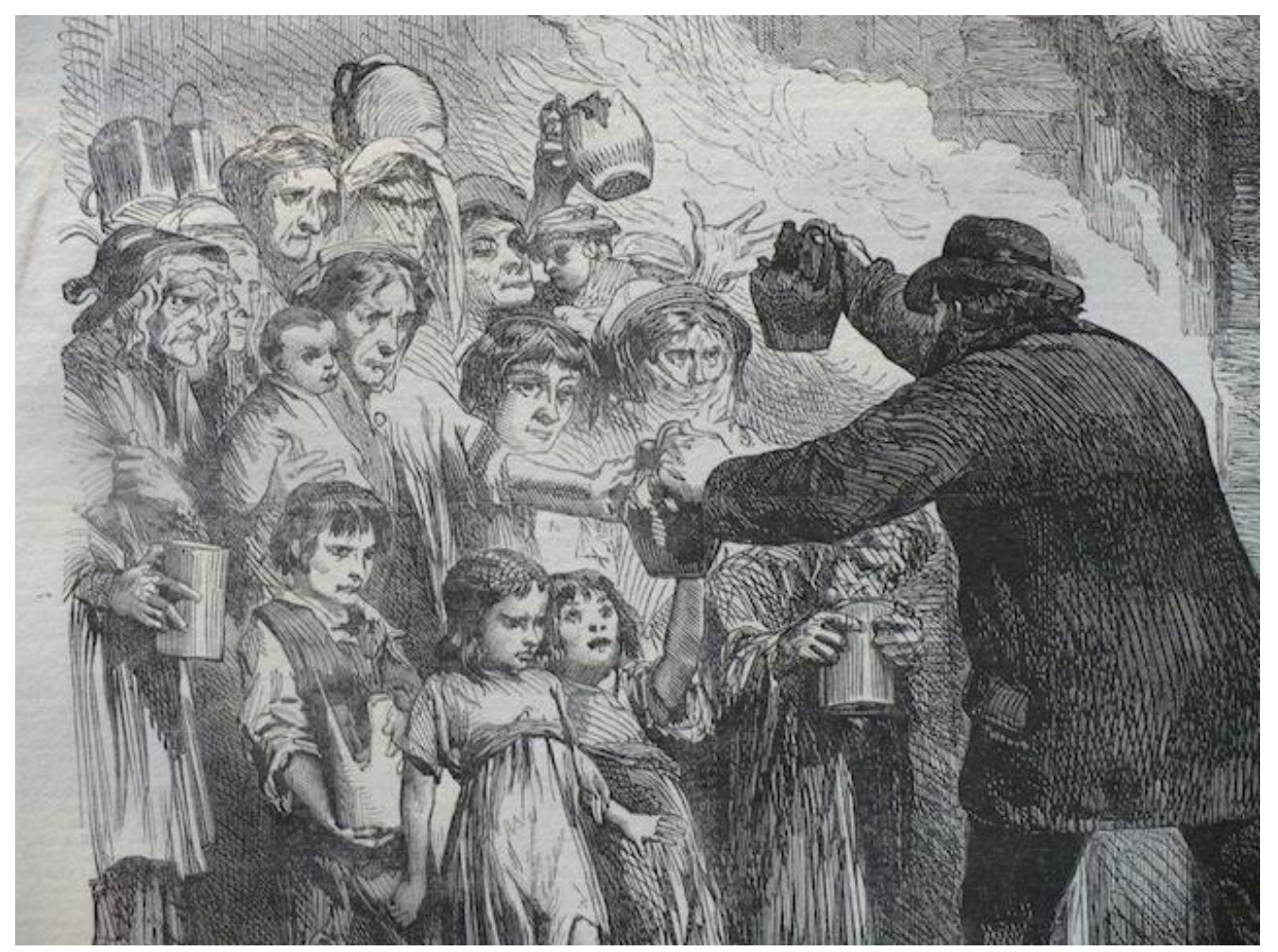

Fig. 7: Matt Somerville Morgan, "The Distress at the East-End.

A Soup-Kitchen in Ratcliff-Highway," Illustrated London News 50 (Feb. 16, 1867) (detail)

Published in February 1867 with a short article appealing for public support, Morgan's drawing gives substance to the accompanying text, which alerts readers to the "large numbers, sometimes amounting to several hundreds, of poor, hungry-looking, half-clad, and destitute 
creatures flock[ing] round the gates, patiently waiting and hoping to get a little of the relief for which there is such an overwhelming number of eager and clamorous applicants." Houfe notes that Morgan, as a prominent draughtsman and painter interested in social questions, often "drew powerful studies of reform demonstrations and the poor in London" (234). In this illustration, he uses physiognomy to relay his message. With their sunken eyes, hollow cheeks, and broken frames, Morgan's East Enders connote "low development on the human scale, whether in the case of an individual, or of an entire race," as Mary Cowling notes in her 1989 study (59-60). According to Ernst Haeckel's "recapitulation" theory, the lower classes of a highly civilised nation resembled the savages in primitive societies, thus promoting the widely shared perception of the urban poor as a "race apart, having darker skin and hair than their social superiors" (Curtis 24). In the late 1840s, Henry Mayhew's survey of the city's poor for the Morning Chronicle, later compiled into the four volumes of London Labour and the London Poor (1851), had already distinguished the "wandering tribes" of the capital as belonging to a different race, a vision also at work in Kenny Meadow's 1848 "Characters about Town" series for the Illustrated London News (Mayhew 1:1; Meadows 298 \& 394). Endowed with "distinctive physical as well moral characteristics," these classes could be identified, Mayhew explained, by their "greater relative development of the jaws and cheekbones" and their "broad lozenge-shaped faces," indicating an enlargement of the "organs subservient to sensations and the animal faculties" (Mayhew 1:1). With their prognathous jaws and receding foreheads, Morgan's "hungry multitudes" allude to the pauper "race" and thus become a signifier of its incongruity ("Distress at the East-End," 152). Instead of depicting actual people and situations, the artist's line traces the clear and decipherable boundary between respectability and deviance, self-reliance and dependence, self and other. Behind the towering figure of the soup-kitchen volunteer stands a middle-class viewer who embodies the collective gaze of middle-class readers on the barbaric crowd, thus reassuring them of their own higher degree of civilisation. Far from the aesthetic satisfaction elicited by the high art filters, caricatural and sometimes grotesque images produce feelings of superiority by dehumanising the working-class other.

The same visual system prevails in a later Graphic sketch entitled "Sunday Afternoon, 1 P.M.-Waiting for the Public House to Open," engraved by E.G. Dalziel (figure 8). Here again, the working-class body appears as an inscription of deviance. In a rather gloomy London setting, a disparate crowd of East Enders waits in line for the pub to open. In a narrative manner inherited from Hogarth and popularised by William Powell Frith's panoramic works such as Ramsgate Sands, Life at the Seaside (1854) or Derby Day (1858), Dalziel provides readers with an "incident-picture," in other words, as a series of readable plots. The viewer's eye is nonetheless immediately drawn towards a rather pathetic young mother sitting on the pavement with her child. Her dejected posture, bent head, and empty basket characterise her as just another Molly Hackabout. ${ }^{6}$ Next to them stands a young and rather neatly dressed woman whose regular profile and light complexion connote a higher

\footnotetext{
${ }^{6}$ Molly Hackabout is the name of the main protagonist in William Hogarth's A Harlot's Progress (1732). In this series of six engravings, Molly arrives in London to find work and becomes a prostitute. She is then arrested, sent to prison and finally dies of syphilis at the age of 23.
} 
degree of respectability. The impoverished mother's hand is on the shoulder of an older man facing her, and she directs her absent gaze towards the right of the frame, as if already numbed by hardship and alcohol. But it is mainly in the background that Mayhew's "wandering tribes" are to be found. And while the four men standing on the right-hand side of the print exhibit dark complexions, prognathous faces, and coarse features, the women waiting in line on the other side are remarkable for their snub noses and prominent cheekbones, an indicator of impropriety.

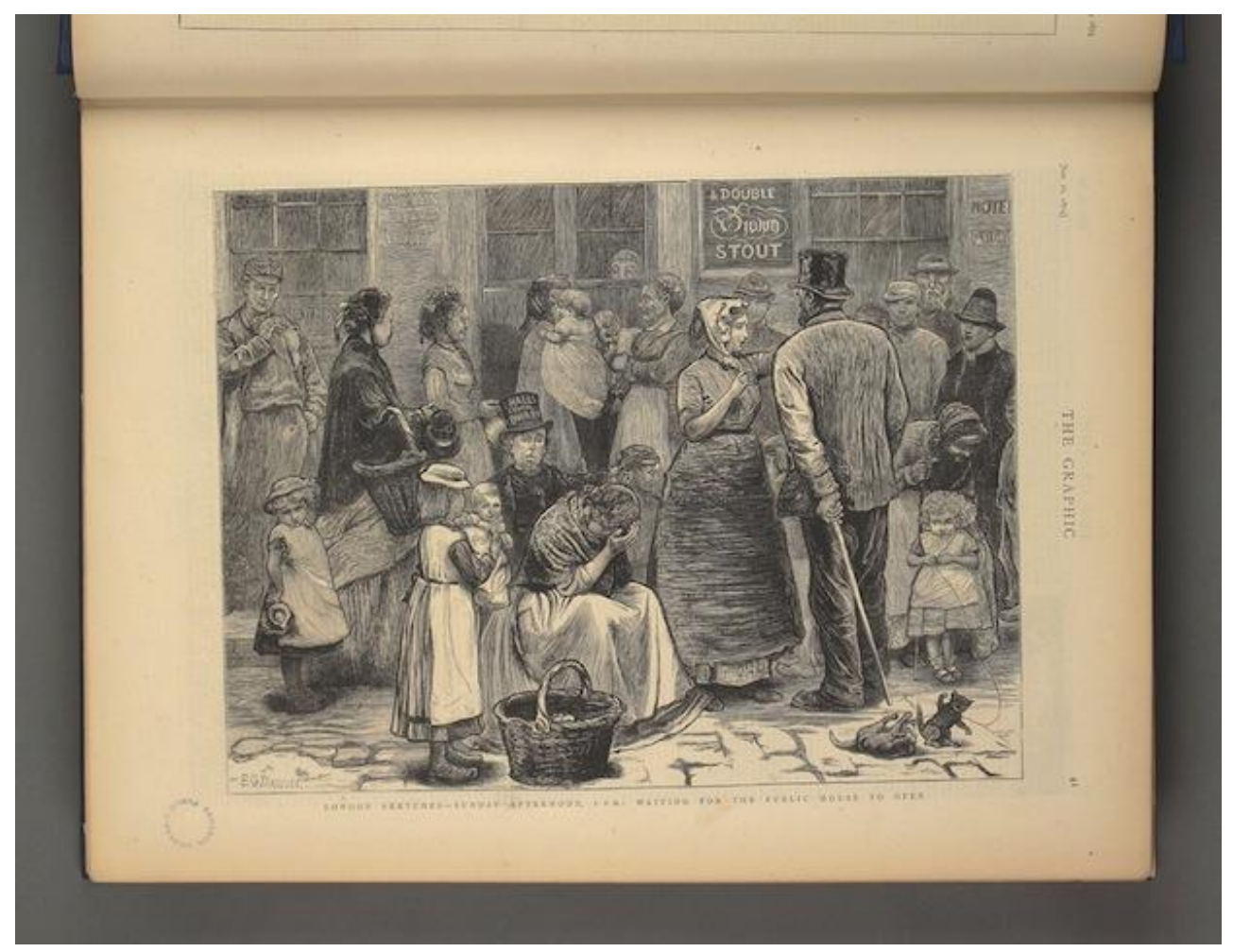

Fig. 8: E.G. Dalziel (engraver), "Sunday Afternoon, 1pm-

Waiting for the Public House to Open," Graphic 9 (Jan. 10, 1874) : 41

As they appear, these men strongly anticipate "The British Rough" (figure 9), a striking representation of the Victorian association between vagrancy and criminality. Published in the Graphic a year later, in June 1875, the "British Rough" was part of a series of character studies entitled "Heads of the People" and inspired from the graphic tradition of physiologies - itself inspired by the writings of Johan Casper Lavater (1741-1801). Its author, William Small, an artist whose activity spread over a wide range of publications including Good Words and the Argosy, provides here "a most astonishing image of brute force," allowing the Illustrated London News reader to classify at once the subject represented as dangerous (Houfe 154). With his low forehead and pronounced prognathism, Small's rough presents the appearance of disreputable characters, his deviant features strongly prefiguring Cesare Lombroso's idea of the atavistic criminal type (Horn 25). A point of intersection between scientific, medical, and political discourses, the British Rough may thus be read as a figure of contagion, disease and death, a male equivalent of the prostitute, "a sign of social disorder and ruin to be feared and controlled" (Nead 106). 


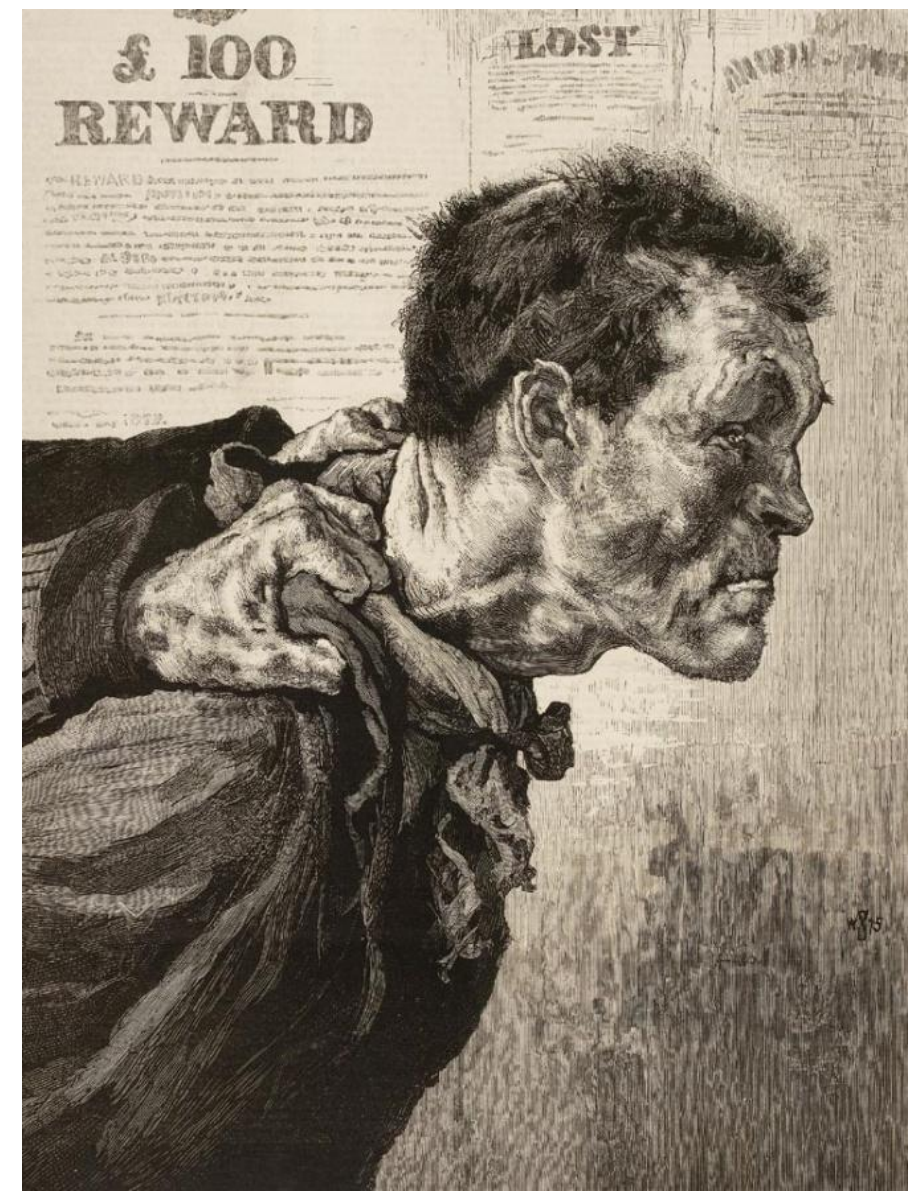

Fig. 9: William Small, “The British Rough,” Graphic 11 (June 26, 1875) : 616

With their badly proportioned heads and coarse features, the "British Rough" and the dependent paupers depicted in the Illustrated London News and the Graphic presented here also suggest a link between the residuum and the concept of degeneracy which peaked in the 1890s with the publication of Max Nordau's Degeneration (1895). As early as the 1860s, social commentators such as Henry Maudsley described the city as a "breeding ground of decay" (Pick 190). In Physiology and Pathology of Mind (1868), Maudsley contended that the overcrowding and poor sanitary conditions of many urban dwellings favoured the emergence of illnesses like scrofula or phthisis which were "generated and transmitted as evil heritages to future generations, the acquired ill of the parent becom[ing] the inborn infirmity of the offspring" (232). Born "without that reserve power necessary to meet the trying occasions of life" (Maudsley 233), the urban degenerate, a "morbid variety of the human kind," was "incapable of being a link in the line of progress of humanity" (Maudsley 45). This widelycirculated discourse, which would have been familiar to an educated middle-class audience, was echoed a few years later by Francis Galton's Inquiry into Human Faculty and its Development (1883) and by social commentators such as Arnold White (and later FreemanWilliams or Cantlie). "The species," Arnold White explains in Problems of a Great City (1886), 
is being propagated and continued increasingly, though not of course exclusively, from the idle, unthrifty, undersized and unfit. As luxury and success corrupt the West-End, the East is corrupted by want and failure. As in the West there are those who, born to wealth, revelling in wealth, are destitute of the qualities by which wealth is won, or its possession made a blessing to the community, so in the East, those born to poverty, wallowing in misery are, many of them, devoid of the qualities by which life is sustained in dignity, if not in comfort, and perpetuated by means of a healthy and capable progeny. (White 29).

At a time when the cultural, social, medical and penal spheres were tightly intertwined, social decadence could undermine and contaminate the whole nation, an exclusionary discourse which William Booth would powerfully reiterate, suggesting the transfer of the "Submerged Tenth" to workshop and farm colonies outside London.

Through the distorting lens of the industrial sublime, derivations from the picturesque or the legacy of caricature, the Victorian illustrated press therefore articulated forceful distinctions between different categories of poverty, between self and other. At a time when contemporaries discussed the social order with "with unprecedented urgency, intensity and anxiety" (Cannadine 62), in particular among the among the middle-class groups to which the Illustrated London News and the Graphic readership largely belonged, the visual taxonomy provided by these periodicals allowed the (re)tracing of boundaries perceived as dangerously blurred. "Who was being brought within the pale of the constitution," Hall, McClelland and Rendall remark, "was a particular man whose definition - the social, political and moral qualities he was thought to carry, his perceived relationship to processes of government and politics - was crucial to the redefinition of what the political nation was and might become" (71).

In the Graphic and the Illustrated London News, representations of dependent paupers through the prism of Regency comedy and caricature reinforced perceptions that they were a distinct race apart from the rest of English society. The theatricality of the black-and-white sketches added to the effect, mapping out social and political territories in an increasingly complex and heterogeneous society. These representational strategies contradicted the filters of high art. Yet all had the effect of obliterating the reality of poverty and supporting the idea of bourgeois legitimacy.

A source of renewed critical interest throughout the $1880 \mathrm{~s}$, the concept of the "residuum" reached its heyday with the publication, in 1890, of William Booth's In Darkest England and the Way Out, which famously described the "submerged tenth" of the population (Welshman 23). A year later, in 1891, the first volume of Charles Booth's Life and Labour of the People of London (1891-1903) was published, insisting on the distinction between residuum and respectable working class. Booth was also-with Alfred Marshall and William Beveridge - among the proponents of a clear political and economic separation of the residuum from the rest of the body politic through the setting up of industrial labour colonies (Harris 78). 


\section{Bibliography}

Anon., "Prisons and Prisoners," The Times (30 September 1874): 12.

Barnett, Harry V. “The Special Artist.” Magazine of Art 6 (1883): 163-70.

Bartram, Michael, The Pre-Raphaelite Camera. Aspects of Victorian Photography. London: Weidenfeld \& Nicolson, 1985.

Beegan, Gerry. The Mass Image: A Social History of Photomechanical Reproduction in Victorian London. Basingstoke: Palgrave Macmillan, 2008.

Bentham, Jeremy. Writings on the Poor Laws. Volume 1. Ed. Michael Quinn. Oxford: Clarendon Press, 2001.

Booth, William. In Darkest England and the Way Out. London: International Headquarters of the Salvation Army, 1890.

Brown, Joshua. Beyond the Lines: Pictorial Reporting, Everyday Life, and the Crisis of Gilded Age America. Berkeley: U of California P, 2002.

Cannadine, David. The Rise and Fall of Class in Britain. New York: Columbia UP, 1993.

Carlyle, Thomas. Past and Present. 1843. Berkeley: U of California P, 2005.

Cowling, Mary. The Artist as Anthropologist: The Representation of Type and Character in Victorian Art. Cambridge: Cambridge UP, 1989.

Victorian Figurative Painting. London: Andreas Papadakis, 2000.

Curtis, L. Perry Jr. Anglo-Saxons and Celts: A Study of Anti-Irish Prejudice in Victorian England. Bridgeport: Published by the Conference on British Studies at the University of Bridgeport, 1968.

Dickens, Charles. "One of the Evils of Match-Making." Household Words. Vol. V (MarchSeptember 1852). London: Bradbury and Evans, 1852. 152-55.

Dobraszczyk, Paul. "Sewers, Wood Engraving and the Sublime." Victorian Periodicals Review 38.4 (2005): 349-78.

Engen, Rodney K. Dictionary of Victorian Wood Engravers. Cambridge: Chadwyck Healey, 1985.

Fox, Celina. "The Development of Social Reportage in English Periodical Illustration During the 1840s and early 1850s." Past and Present 49 (January-May 1977): 90-111.

_. Graphic Journalism in England during the 1830s and 1840s. London: Garland, 1988.

Freeman, Mark and Gillian Nelson, eds. Vicarious Vagrants. Incognito Social Explorers and the Homeless in England, 1860-1910. Lambertville, NJ : The True Bill Press, 2008.

Goldman, Paul. Victorian Illustration: The Pre-Raphaelites, the Idyllic School and the High Victorians. Aldershot: Ashgate, 1996. 
Goldman, Paul and Simon Cooke, eds. Reading Victorian Illustration, 1855-1875. Spoils of the Lumber Room. Farnham: Ashgate, 2012.

Hall, Catherine, McClelland, Keith and Jane Rendall. Defining the Victorian Nation. Class, Race, Gender and the British Reform Act of 1867. Cambridge: CUP, 2000.

Harris, José. "Between Civic Virtue and Social Darwinism: The Concept of the Residuum." Retrieved Riches: Social Investigation in Britain 1840-1914. Eds. David Englander and Rosemary O’Day. Aldershot: Scolar Press, 1995. 67-87.

Hatton, Joseph. Journalistic London. London: Sampson Low, Marston, Searle \& Rivington, 1882.

Himmelfarb, Gertrude. "The Culture of Poverty.",The Victorian City. Eds. H. J. Dyos and Michael Wolff. Vol. 2. London: Routledge and Kegan Paul, 1973. 707-36.

Hoppen, K. Theodore. The Mid-Victorian Generation, 1846-1886. Oxford: Clarendon Press, 1998.

Horn, David G. The Criminal Body. Lombroso and the Anatomy of Deviance. New York and London: Routledge, 2003.

Houfe, Simon. The Dictionary of 19th Century British Book Illustrators and Caricaturists. Woodbridge: Baron Publishing, 1978.

Jackson, Mason. The Pictorial Press: Its Origins and Progress. London: Hurst and Blackett, 1885.

Johnson, Herbert. “The Matchmakers at the East-End.” Graphic 3 (Jan-June 1871): 467.

Klingender, Francis D. Art in the Industrial Revolution. London: Evelyn, Adams and Mackay, 1968.

Korda, Andrea. Printing and Painting the News in Victorian London. The Graphic and Social Realism, 1869-1891. Farnham: Ashgate, 2015.

Lorimer, Douglas A. Colour, Class and the Victorians. Leicester: Leicester UP, 1978.

Maidment, Brian. Comedy, Caricature and the Social Order 1820-50. Manchester: Manchester UP, 2013.

Maudsley, Henry. Body and Mind: An Inquiry into their Connection and Mutual influence, Specially in Reference to Mental Disorders. London: Macmillan and Co., 1870.

_. Physiology and Pathology of Mind. London: Macmillan and Co., 1868.

Mayhew, Henry. London Labour and the London Poor. Vol. 1. New York: Dover, 1968.

Meadows, Kenny. "Characters about Town: The Dram-Drinker.” Illustrated London News 12 (Jan-June 1848): 298. 
—. "Characters about Town: The Crossing-Sweeper." Illustrated London News 12 (JanJune 1848): 394.

Murdoch, Lydia. Daily Life of Victorian Women. Santa Barbara: ABC CLIO, 2014.

Mussell, James. The Nineteenth-Century Press in the Digital Age. Basingstoke: Palgrave Macmillan, 2012.

Nead, Lynda. Myths of Sexuality. Representations of Women in Victorian Britain. Oxford: Basil Blackwell, 1988.

Pick, Daniel. Faces of Degeneration A European Disorder, c.1848- c.1918. Cambridge: Cambridge UP, 1989.

Raw, Louise. Striking a Light: The Bryant and May Matchwomen and their Place in History. London: Continuum, 2011.

Scott, William Bell. Half-hour Lectures on the History and Practice of the Fine and Ornamental Arts. London: Longmans, Green and Co., 1874.

Sinnema, Peter. Dynamics of the Pictured Page: Representing the Nation in the Illustrated London News. Aldershot: Ashgate, 1998.

Small, William. “The British Rough,” The Graphic 11 (26 June 1875): 616.

Smith, Sheila. “'Savages and Martyrs': Images of the Urban Poor in Victorian Literature and Art." Victorian Artists and the City. Ed. Ira B. Nadel and F.S. Schwarzbach. New York: Pergamon Press, 1980. 14-29.

Sussman, Herbert. Victorian Masculinities. Cambridge: Cambridge UP, 1995.

Vann, J. Don and Rosemary T. VanArsdel, eds. Victorian Periodicals and Victorian Society. Toronto: U of Toronto P, 1994.

Vorspan, Rachel. "Vagrancy and the New Poor Law in Late-Victorian and Edwardian Britain.” English Historical Review, 92, (January 1977): 59-81.

Welshman, John. Underclass: A History of the Excluded since 1880. London: Bloomsbury, 2013.

White, Arnold. The Problems of a Great City. London: Remington, 1886.

Wolff, Michael and Celina Fox. "Pictures from the Magazines." The Victorian City. Eds. H. J.

Dyos and Michael Wolff. Vol. 2. London: Routledge and Kegan Paul, 1973. 559-82.

Wood, Christopher, ed. Victorian Painters. Dictionary of British Art. Volume IV.

Woodbridge: Antique Collectors' Club, 1995.

Young, Alan R. Punch and Shakespeare in the Victorian Era. Oxford: Peter Lang, 2007. 